\title{
Palynological Zonation of Oligocene to Early Miocene Sediments of Greater Ughelli Depobelt, Niger Delta Basin
}

\author{
"LUCAS, FA; FREGENE, TJ
}

\author{
"Department of Geology, University of Benin, Benin City, Nigeria.*Email: drfalucas@gmail.com, talktobabat4us@yahoo.com
}

\begin{abstract}
Palynological zonation of Oligocene to Early Miocene sediments of Greater Ughelli Depobelt Niger Delta Basin was carried out using One hundred and ninety (190) ditch cutting samples ranging from $20 \mathrm{ft} .-11,820 \mathrm{ft}$. $(6.09 \mathrm{~m}-$ $3603.7 \mathrm{~m}$ ), by identifying the different species of palynomorphs present as well as using stratigraphic significant diagnostic palynomorphs to age date and zone the well section, Nine hundred and sixty four (964) species of palynomorps were recovered.Nine hundred and fifty four (954) were miospores(pollen and spore) and ten(10) were Dinocysts.The presence of diagnostic palynomorphs such as Praedapollis africanus, Peregrinipollis nigericus, Retibrevitricolporites obodoensis aided in the establishment of the age and three P-zones in the well. The age of the well section range from Oligocene to Early Miocene.The P-zones established are P560, P580 and P620 zones. P620 and P580 Zones were lumped together and was established based on the occurrence of Top Pradapollis africanus at $4500 \mathrm{ft}$ and quantitative base of Peregrinipollis nigericus at $7620 \mathrm{ft}$.This zone were lumped together because Top/FDO Cicatricosisporites dorogenesis (30)/Gemmatriporites $s p$ (573) which represents the base of P620 zone and top of P580 zone were undefined.P560 Zone was defined by the appearance of quantitative base Peregrinipollis nigericus at $7620 \mathrm{ft}$ and increase Retibrevitricolporites obodoensis at $11580 \mathrm{ft}$.

DOI: https://dx.doi.org/10.4314/jasem.v21i7.21
\end{abstract}

Copyright @ 2017 Lacus and Fregene. This is an open access article distributed under the Creative Commons Attribution Non-Commercial License (CC-BY-NC), which permits unrestricted use, distribution, and reproduction in any medium, provided the original work is properly cited.

Received 01 October 2017, received in revised form 20 November 2017, accepted 31 December 2017.

Keywords: Lithozones; Niger delta Basin; Palynomorphs; Oligocene to Early Miocene; Depobelt

The Niger Delta is the most significant hydrocarbon province on the West African continental margin. It lies mainly in the Gulf of Guinea to the southwest of the Benue - Trough and constitutes the most important Cenozoic deltaic construction in the south Atlantic. Because of its petroliferous nature, the economy of Nigeria depends largely on the oil and gas derived from it. The Cenozoic Niger Delta is situated at the intersection of the Benue Trough and the South Atlantic Ocean where a triple junction developed during the separation of South America and Africa in the Late Jurassic (Whiteman, 1982). Geologically it is found in the Tertiary period in the geologic column. The combination of source rock, lithologic types, structures and thermal history of the basin are favorable for the generation, accumulation and retention of hydrocarbons (Whiteman, 1982; Stacher, 1995). The use of lithofacie and palynology as tools and components in evaluating sedimentary pile and basin analysis has become increasingly important in recent times as seen in works by (Germeraad et al., 1968;Oloto, 1994;Chiaghanam et al., 2013; Lucas, 2017).

Biostratigraphy is an essential tool for dating rocks and identifying the biotic record through time and is necessary for establishing temporal correlation, reconstructing paleogeography as well as recognition of oil and gas deposits and intervals. It is essential to the petroleum industry as a tool for defining geologic constraints on prediction of exploration risk and modeling reservoir simulation.(Allmon, 1993) stated that paleontology is still a necessary geologic tool because the geologic time scale is based on fossils, fossils are still the primary tool for dating sedimentary rocks and fossils records the history of life and environmental changes.

This study is aimed at establishing a palynological zonation framework of sedimentary succession penetrated by the drill.

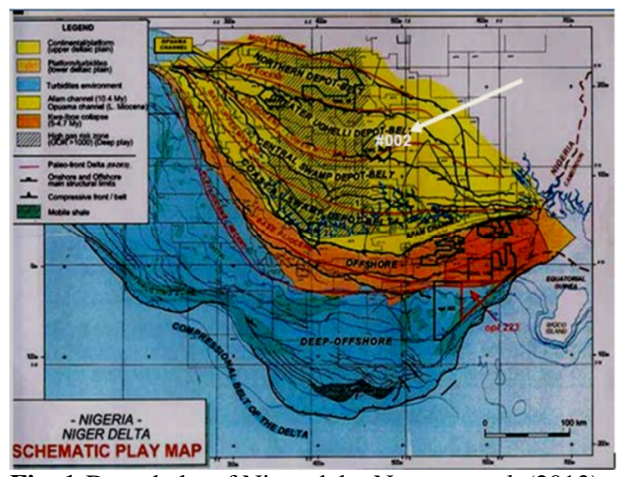

Fig. 1:Depo belts of Niger delta Nwozoret al.,(2013)

\section{MATERIALS AND METHOD}

Fifty (50)selected ditch cutting samples were collected from the well ranging from $20 \mathrm{ft}$. $(6.09 \mathrm{~m})$ to $11,820 \mathrm{ft}$. $(3603.7 \mathrm{~m})$ were utilized for palynological slide 
preparation. The slides were analyzed under the microscope for palynological content.

Palynological Sample Preparation: The sample preparation was carried out following the international standards given below:

$10 \mathrm{~g}$ of sample was crushed between aluminum pie dishes, collected and tested for limestone $\left(\mathrm{CaCO}_{3}\right)$ using $\mathrm{HCl}$, while effervescence occurred, the limestone was eliminated by further addition treatment with concentrated $\mathrm{HCl}$.

After two or three hours, the sample was decanted and the waste solution transferred to one special waste container bottle. The broken down mineral material and fossils were removed and centrifuged for about 1-2 minutes and decanted repeatedly until a neutral reaction was reached. Concentrated $\mathrm{HNO}_{3}$ was used for oxidization and heated over bunsen burner. $\mathrm{KOH}$ of $10 \%$ solution was added to the sample and transferred to styrofoam cups and HF added and let to stand overnight. The sample was then washed with water until a neutral reaction was reached and decanted. Sodium hypochlorite (Purex) as well as some drops of $\mathrm{HCl}$ was added, agitated and let for about 15 minutes. Two drops of Ammonium Hydroxide concentrate was added and diluted with water. At this stage, separation of the organic matter from the inorganic material (silica) was done by floatation using diluted zinc bromide $(\mathrm{ZnBr})$. The samples were transferred to a flexible plastic tubes, already prepared (cut and mount immersed into warm water); such plastic tubes are set into centrifuge tubes with water around them. Zinc bromide has a specific gravity of 2.2 thus, everything with a specific gravity of more than 2.2 will settle down. The process of centrifugation using zinc bromide took about 15 minutes. A small portion of the supernatant liquid was observed under the microscope. Then, a clip across the flexible plastic tube was inserted so that the supernatant liquid would be easy to take out by pipette decantation or eye dropper.

Palynomorphs Distribution Chart: A palynomorph distribution chart was established based on the first appearance datum (last downhole occurrence) and last appearance datum (first downhole occurrence) of each palynomorph identified in the well section. The recovered Miospores are as follows:

Miospores recovered are:Polypediaceisporites, Verrucatosporites usmensis, Dichtyphidiles harassi, Crototricolpites crotonoisculptus, Echiperiporites estelae, Smooth trilate spore cf. Acrostichun aureum,
Pradapollis africanus, Retibrevitricolporites obodoensis, Laevigatosporites smooth monolete spore, Classopollis, Retitricolporites irregularis, Proxapertites operculatus , Praedapollis flexibilis, Psilatricolporites crassus, Sapotaceae pollenites , Pachydemites diederixi, Psilamonocolpites marginatus , Arecipites exilimuratus, Striatmonocolpites rectostriatus, Striatricolpites catatumbus, Monoporites annulatus, Numulipollis neogenicus, Verrucatosporites usmensis, Stereisporites , Zonocostites ramonae, Spirosincoporites brunnii , Polygalaceae, Cinctiperiporites mulleri, Racemonocolpites hians, Grimsdalea baculatus, Magnastriatites, Cyperoceapollis sp , Retimonocolpites obaensis, Magnastriatites hawardi, Racemonocolpites rarispinosus, Psilaheterecolpites, Pediastrum,Belskipollis elegans, Polyadopollenites vancampori, Bombacacidites, Echitricolpolrites spinosus, Ericipites.

Recovered Palynomorphs that were stratigraphically significant and environmentally necessary were plotted in order to interpret the P-zones and zonal age dating of the well See plate 1 and tables 2.

Microscopic view of the supernatant liquid decided how to clean, run acetolysis or stain. Add acetic anhydride and three of four drops of $\mathrm{H}_{2} \mathrm{SO}_{4}$ to take out the water, then immerse test tube in boiling water for about ten minutes. The sample was properly washed at each stage. Here, it was ready for cleaning and mounting; during this stage several views under the microscope accomplished with some attempt to get mainly fossil material was done. The palynomorph counting and logging were done by straight transects across each slide and coordinates. The recovered palynomorphs species were identified with the aid of Shell palynological photo album, other relevant publications and manuals such as web-based albums. Morphological characters of the pollens and spores such as the size, exine, structure, shape, sculpture and aperture type provided the basis for the identification of the forms. Species name and their abundance were recorded in the analysis data sheets.

\section{RESULT AND DISCUSSION}

Palynomorphs that were stratigraphically significant and environmentally necessary were recovered in the analyzed samples and were plotted in order to interpret the Palynostratigraphy/P-zones and age of the well section. The pollen and spores recovered are relatively moderate in abundance.

Palynological Count:From the analyzed palynological slides, Nine hundred and sixty four (964)palynomorphs species were identified.Nine hundred and fiftyfour (954) were Miospore (pollen and spore) and ten 
(10)were Dinocysts. The palynomorph distribution with depth is shown in table 1.

.Table 1: Occurrence and distribution of Palynomorphs

\begin{tabular}{|c|c|c|c|c|c|c|c|}
\hline $\mathbf{S} / \mathbf{N}$ & $\begin{array}{l}\text { DEPTH } \\
\text { (ft.) }\end{array}$ & $\begin{array}{l}\text { DEPTH } \\
(\mathrm{m})\end{array}$ & POLLEN & SPORES & MIOSPORES & DINOCYSTS & $\begin{array}{c}\text { TOTAL } \\
\text { PALYNOMORPHS }\end{array}$ \\
\hline 1. & 1640 & 500 & 0 & 8 & 8 & 2 & 10 \\
\hline 2. & 1760 & 536 & 2 & 0 & 2 & 0 & 2 \\
\hline 3. & 1940 & 591 & 0 & 5 & 5 & 3 & 8 \\
\hline 4. & 4500 & 1372 & 7 & 5 & 12 & 3 & 15 \\
\hline 5. & 4560 & 1390 & 10 & 1 & 11 & 0 & 11 \\
\hline 6. & 4620 & 1408 & 8 & 3 & 11 & 0 & 11 \\
\hline 7. & 4680 & 1426 & 6 & 1 & 7 & 0 & 7 \\
\hline 8. & 4820 & 1469 & 14 & 5 & 19 & 0 & 19 \\
\hline 9. & 5040 & 1536 & 3 & 7 & 10 & 0 & 10 \\
\hline 10. & 5100 & 1554 & 12 & 9 & 21 & 0 & 21 \\
\hline 11. & 5340 & 1628 & 6 & 20 & 26 & 0 & 26 \\
\hline 12. & 5400 & 1646 & 32 & 20 & 52 & 0 & 52 \\
\hline 13. & 5460 & 1664 & 18 & 7 & 25 & 0 & 25 \\
\hline 14. & 5580 & 1701 & 6 & 13 & 19 & 0 & 19 \\
\hline 15. & 5700 & 1737 & 8 & 19 & 27 & 0 & 27 \\
\hline 16. & 5820 & 1774 & 4 & 8 & 13 & 0 & 13 \\
\hline 17. & 5980 & 1823 & 10 & 8 & 18 & 0 & 18 \\
\hline 18. & 6100 & 1859 & 7 & 11 & 18 & 0 & 18 \\
\hline 19. & 6220 & 1896 & 8 & 10 & 18 & 0 & 18 \\
\hline 20. & 6340 & 1932 & 4 & 7 & 11 & 0 & 11 \\
\hline 21. & 6400 & 1951 & 11 & 14 & 25 & 1 & 26 \\
\hline 22. & 6520 & 1987 & 8 & 15 & 23 & 0 & 23 \\
\hline 23. & 6580 & 2006 & 9 & 8 & 17 & 0 & 17 \\
\hline 24. & 6700 & 2042 & 14 & 16 & 30 & 0 & 30 \\
\hline 25. & 6940 & 2115 & 12 & 18 & 30 & 0 & 30 \\
\hline 26. & 7060 & 2152 & 10 & 13 & 23 & 0 & 23 \\
\hline 27. & 7180 & 2188 & 2 & 6 & 8 & 0 & 8 \\
\hline 28. & 7300 & 2225 & 4 & 7 & 11 & 0 & 11 \\
\hline 29. & 7440 & 2268 & 44 & 38 & 82 & 0 & 82 \\
\hline 30. & 7620 & 2323 & 32 & 19 & 51 & 0 & 51 \\
\hline 31. & 7800 & 2377 & 35 & 16 & 51 & 0 & 51 \\
\hline 32. & 7860 & 2396 & 28 & 18 & 46 & 0 & 46 \\
\hline 33. & 8060 & 2457 & 6 & 8 & 14 & 0 & 14 \\
\hline 34. & 8180 & 2493 & 7 & 13 & 20 & 0 & 20 \\
\hline 35. & 11040 & 3365 & 17 & 14 & 31 & 0 & 31 \\
\hline 36. & 11100 & 3383 & 20 & 14 & 34 & 0 & 34 \\
\hline 37. & 11160 & 3402 & 17 & 11 & 28 & 0 & 28 \\
\hline 38. & 11280 & 3438 & 21 & 14 & 35 & 1 & 36 \\
\hline 39. & 11400 & 3475 & 6 & 2 & 8 & 0 & 8 \\
\hline 40. & 11580 & 3530 & 15 & 9 & 24 & 0 & 24 \\
\hline 41. & 11640 & 3548 & 7 & 7 & 14 & 0 & 14 \\
\hline 42. & 11760 & 3584 & 6 & 10 & 16 & 0 & 16 \\
\hline \multicolumn{5}{|c|}{ TOTAL } & 954 & 10 & 964 \\
\hline
\end{tabular}
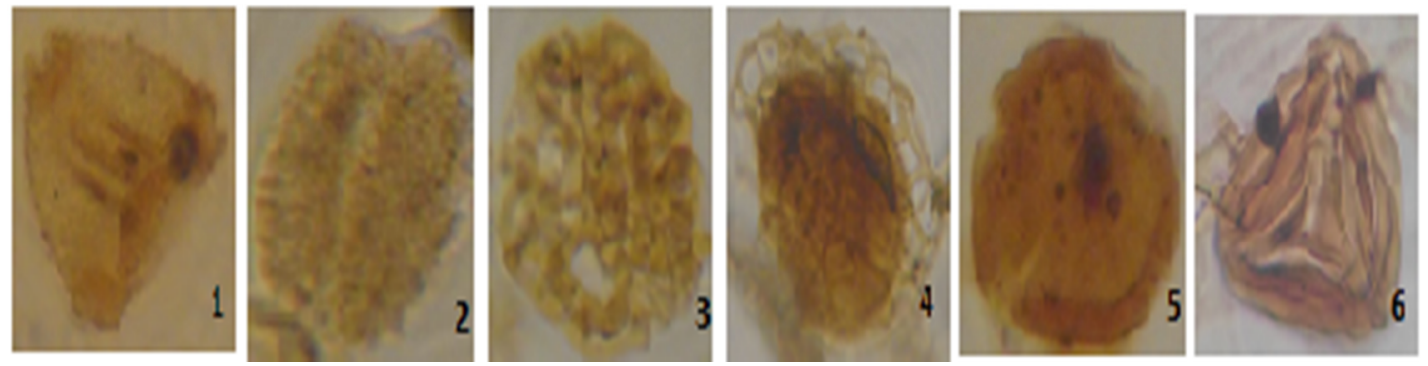

Plate 1: 1. Retibrevitricolporites obodoensis (178), 2. Racemonocolpites hians (250), 3. Peregrinipollis nigericus (399, 4. Praedapollis africanus(443), 5. Pachydemites diederixi (317), 6. Magnastriatites hawardi (9) 
Table 2: Range Chat of recovered diagnostic Palynomorphs

\begin{tabular}{|c|c|c|c|c|c|c|c|c|c|c|c|c|c|c|c|c|c|c|}
\hline 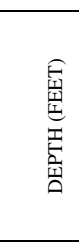 & 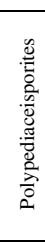 & 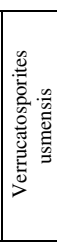 & 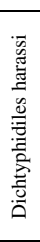 & 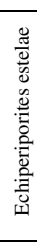 & 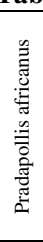 & 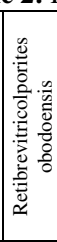 & 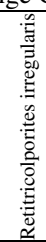 & 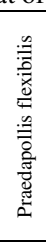 & 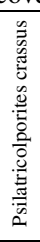 & 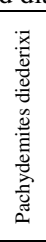 & 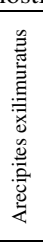 & 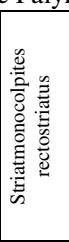 & 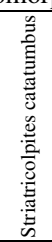 & 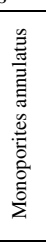 & 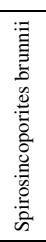 & 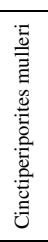 & 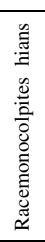 & 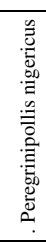 \\
\hline 1640 & 1 & 3 & 4 & & & & & & & & & & & & & & & \\
\hline 1760 & & & & 1 & & & & & & & & & & & & & & \\
\hline 1940 & & & 3 & 1 & & & & & & & & & & & & & & \\
\hline 4500 & 1 & & 3 & & 2 & 1 & 2 & & & & & & & & & & & \\
\hline 4560 & & & & & & 1 & 3 & 3 & 1 & & & & & & & & & \\
\hline 4620 & & & 2 & & & & 2 & & & & & & & & & & & \\
\hline 4680 & 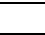 & & 1 & & & & 2 & & & 1 & & & & & & & & \\
\hline 4820 & & 2 & 1 & & & 1 & 2 & & & & 1 & 2 & 1 & 1 & & & & \\
\hline 5040 & & 3 & 1 & & & & & & & & & & 1 & & & & & \\
\hline 5100 & 1 & & & & & & 1 & & & & 1 & & & 1 & 1 & T & & \\
\hline 5340 & & 3 & & & & & 3 & & & & & & & 1 & & & & \\
\hline 5400 & , & 4 & 3 & & & & 4 & & 2 & 1 & 3 & & & & 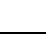 & 1 & 2 & \\
\hline 5460 & 1 & 2 & 1 & & 2 & & 5 & & 2 & & & 1 & & & 1 & & & \\
\hline 5580 & 1 & & & & & 1 & & & & 1 & & & & & & & & \\
\hline 5700 & 3 & 2 & 2 & & & & & & 1 & & 2 & & & & & & & \\
\hline 5820 & 2 & & & & & & & & & & 3 & & & & & & & \\
\hline 5980 & 2 & & & & & & & & & 1 & 3 & & & & & & & \\
\hline 6100 & 1 & 1 & & & & & 2 & & & & 3 & & 1 & & 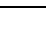 & & & \\
\hline 6220 & & 2 & 3 & & 1 & & 3 & 1 & & & & & & & & & & \\
\hline 6340 & & 4 & & & & & & & & & 1 & & & & 1 & & & \\
\hline 6400 & 1 & 1 & & & 1 & & 4 & & & & 1 & & & & & & & \\
\hline 6520 & 3 & 4 & 2 & & & & 4 & & 1 & & 1 & & & & & & & \\
\hline 6580 & 1 & & 1 & & & & 1 & & 1 & & 1 & & & & & & & \\
\hline 6700 & 2 & 1 & & & & & & & & & 5 & & & & & & 3 & \\
\hline 6940 & 3 & 6 & 2 & & & & 2 & 2 & & & & 1 & & & & & 1 & \\
\hline 7060 & 3 & 6 & & & & & 3 & 2 & & & 3 & & & & & & 1 & \\
\hline 7180 & 1 & & 2 & & & & & & & & & & & & & & & \\
\hline 7300 & & & 1 & & & & & 1 & & & & & & 1 & & & 1 & \\
\hline 7440 & 1 & 28 & 3 & & & & 1 & & & & 11 & 4 & & & & & 9 & \\
\hline 7620 & 6 & & 3 & & 3 & 1 & 4 & & & 1 & 4 & & & 1 & 1 & & 2 & 1 \\
\hline 7800 & 1 & 7 & 3 & & 2 & & & 2 & & & & & 2 & 1 & 2 & 2 & 6 & \\
\hline 7860 & 2 & 8 & & 1 & 2 & & 2 & & & & 3 & 1 & & 2 & & & 1 & \\
\hline 8060 & 2 & 3 & & & 1 & & & & & & & & & & 2 & & 1 & \\
\hline 8180 & 2 & 1 & 2 & & & & 6 & & & 1 & & & & & & & & \\
\hline 11040 & & 5 & 2 & & 1 & & 3 & 2 & & 2 & 2 & 1 & 1 & & & 1 & 2 & \\
\hline 11100 & 1 & 3 & 2 & & & 2 & & & & 3 & 3 & 1 & & & 1 & & 2 & \\
\hline 11160 & & & & & & & & & & & 4 & & & & & & 3 & \\
\hline 11280 & 2 & 4 & 2 & & 2 & & & 1 & & & 5 & 2 & & & & & & \\
\hline 11400 & & & & & & & & & & 2 & & & & & 1 & & & \\
\hline 11580 & 2 & 6 & & & 2 & 2 & 1 & & & 2 & 4 & 1 & & 2 & & 1 & & \\
\hline 11640 & 1 & & 4 & & 2 & & & & & & 1 & & & & & & 1 & \\
\hline 11760 & 1 & 2 & 1 & & & & & 2 & & & 2 & 1 & & & & & & \\
\hline
\end{tabular}

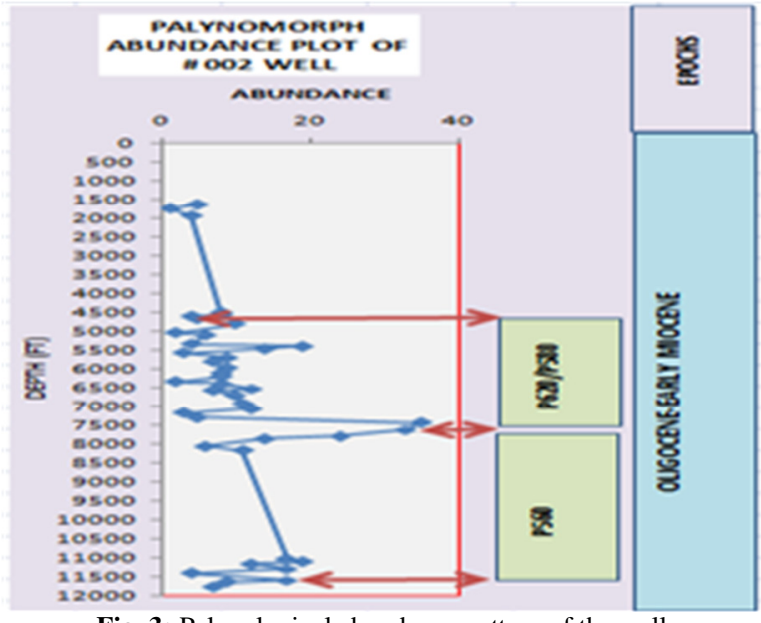

Fig. 3: Palynological abundance pattern of the well
Palynological Zones: P620 and P580 Zones: This zones were lumped together and was established based on the occurrence of Top Pradapollis africanus at $4500 \mathrm{ft}$ and quantitative base of Peregrinipollis nigericus at $7620 \mathrm{ft}$.This zone was lumped together because the Top/FDO Cicatricosisporites dorogenesis (30)/Gemmatriporites sp (573) which represents the base of P620 zone and top of P580 zone were undefined.

P560 Zone: Top of this zone was defined by the appearance of quantitative base Peregrinipollis nigericus at $7620 \mathrm{ft}$ and and increase Retibrevitricolporites obodoensis at $11580 \mathrm{ft}$.

Age Determination: The presence of diagnostic palynomorphs such as Praedapollis africanus, Peregrinipollis nigericus, Retibrevitricolporites 
obodoensis aided in the establishment of P620, P580 and P560 Zones which concurs with the Oligocene to Early Miocene Age of paralic sequence Doust and Omatsola, (1990).

Conclusion: The Palynological analysis of the studied samples was used to determine the Palynological zonation and age of the sediments penetrated by the drill.

The presence of diagnostic palynomorphs such as Praedapollis africanus, Peregrinipollis nigericus, Retibrevitricolporites obodoensis aided in the establishment of the age and P-zones in the well.

Acknowledgement: The authors are grateful to Nigerian Petroleum Development Company (NPDC) Benin and Earth Probe Ltd Lagos for their assistance in this research.

\section{REFERENCES}

Allmon, WD., (1993). In Defense of Paleontology. Geotimes. November 1993, p. 1-5.

Chiaghanam, OI., Nwozor, KK., Chiadikobi, KC., Omoboriowo, AO., Soronnadi-Ononiwu, C G., Onuba, LN., Ofoma, AE (2013). Lithofacies, Palynology and Paleoenvironmental Study of Early Campanian to Mid-Maastrichtian Deposits of Udi and Environs. Int. Journ. of Sci. and Tech, Vol. 2, p. 14-16.

Lucas, FA., (2017). Microphytoplankton and Geological Boundaries in Maastrichtian to Lutetian Succession of Ajire-1 well, Anambra Basin,
Nigeria. International Journal of Science and Advanced Innovative Research, Vol. 2(1), p. 49-65

Lucas, FA., (2017). Miospores and Geological Boundaries in Maastrichtian to Lutetian Succession of Ajire-1 well, Anambra Basin, Nigeria. International Journal of Science and Advanced Innovative Research, Vol. 2(1), pp. 74- 84

Nwozor, KR., Omudu, MI., Ozumba, BM., Egbuachor, CJ., Onwuemesi, AG., Anike, OL.,( 2013). Quantitative evidence of secondary mechanisms of overpressure generation: Insights from parts of Onshore Niger Delta, Nigeria, petr. Techn. Dev. Jour., Vol. 3(1), p. 64-83.

Oloto, IN., (1994). Nigerian Maastrichtian to Miocene Dinoflagellate and miospore Biozonation- A summary, Journal of Mining and Geoscience, Vol. 30, p. 61-73.

Stacher, P., (1995). Present understanding of the Niger Delta hydrocarbon habitat, In: Oti, MN. and Postma, G. (Eds.), Geology of Deltas: Rotterdam, A. A. Balkema, p. 257-267.

Whiteman, AJ., (1982). Nigeria: Its Petroleum Geology, Resources and Potential. Graham and Trotman, London. p. 1-394.

Germeraad, JH., Hopings, CA., Muller, J., (1968). Palynology of Tertiary Sediments from tropical areas. Reviewof Paleobotany and Palynology. Elsevier publishing company, Amesterdam 6, (1968), p. 189-348. 